\title{
SERUM DIPHENYLAMINE REACTION IN RHEUMATOID ARTHRITIS
}

\author{
BY \\ ELVIO CECCHI AND FABRIZIO FERRARIS \\ From the Rheumatic Centre, Rome. Director: Prof. T. Lucherini
}

(RECEIVED FOR PUBLICATION MAY 6, 1955)

Normal human serum in contact with Dische's diphenylamine reagent produces a reddish-purple colour; this is increased in such conditions as cancer, pulmonary tuberculosis, and rheumatic fever (Niazi and State, 1948). According to Coburn and others (1953) and Coburn and Haninger (1954), connective tissue is a rich source of the diphenylamine-reactive substance, the concentration of which in the blood stream as detected by the diphenylamine reaction increases principally during a sterile inflammatory reaction and appears to be conditioned by the intensity of the inflammatory process. In rheumatic fever, the diphenylamine reaction is much more intense in the acute phase, decreases with the lessening of the symptoms, and returns to normal with their subsidence; it parallels in most cases the erythrocyte sedimentation rate; it is inhibited by "antiphlogistic" drugs, such as salicylates, cortisone, and hydrocortisone (Ayala, Moore, and Hess, 1951). Therefore serial diphenylamine determinations are helpful both in estimating the degree of rheumatic activity and in evaluating the efficacy of therapeutic agents.

The substance in the serum which reacts with diphenylamine to produce the purple colour has not been certainly identified. It may be a mucoprotein, with a very low iso-electric point (less than 2 ), the reddish-purple colour being due to the carbohydrate of the mucoprotein found in the $\alpha$-globulin fraction.

The present report includes a study of the diphenylamine values in thirty patients with rheumatoid arthritis, comparing the variations with changes in the clinical picture and erythrocyte sedimentation rate (Westergren measurements at one hour). The values in eight cases of ankylosing spondylitis, and one case of acute disseminated lupus erythematosus are also included.

\section{Method}

The technique used was the semimicro-procedure described by Ayala, Moore, and Hess (1951).

The readings were made with the Unicam spectrophotometer, model SP 350 , with a wave length of $530 \mathrm{~m} \mu$, using $\frac{1}{2}$-in. test-tubes. The results are calculated in colorimetric units $\left(\log . I^{\circ} / \mathbf{I}\right)$.

Our normal values differ from those of Ayala, Moore, and Hess (1951) who used a Coleman spectrophotometer, model 6A. We have therefore established our own "normal" values, using the serum of thirty individuals with no acute disease. The optical density obtained ranged from a maximum of $0 \cdot 140$ to a minimum of $0 \cdot 120$, with a mean of $0 \cdot 134$ and a maximum variation of 0.020 units. These figures were used as our basic values.

\section{Results}

The diphenylamine reaction was studied in thirty patients with rheumatoid arthritis, of whom eight were in the third and fourth stages, ${ }^{*}$ and 22 in the first and second stages.*

In the first group (three men and five women between the ages of 25 and 65), colorimetric values within normal limits were constantly found, that is from $0 \cdot 120$ to $0 \cdot 140$ (mean $0 \cdot 134$ ); the erythrocyte sedimentation rate was also within normal limits (Table I).

TABLE I

DIPHENYLAMINE REACTION AND E.S.R. DETERMINATIONS IN EIGHT PATIENTS WITH

RHEUMATOID ARTHRITIS IN STAGES III AND IV

\begin{tabular}{c|c|c|c}
\hline & Age & $\begin{array}{c}\text { Erythrocyte } \\
\text { Sedimentation } \\
\text { Rate }\end{array}$ & $\begin{array}{c}\text { Diphenylamine } \\
\text { Reaction }\end{array}$ \\
\hline m & 56 & 8 & $0 \cdot 125$ \\
m & 40 & 12 & $0 \cdot 133$ \\
m & 65 & 25 & $0 \cdot 120$ \\
f & 32 & 36 & $0 \cdot 137$ \\
f & 30 & 10 & $0 \cdot 140$ \\
f & 28 & 5 & $0 \cdot 130$ \\
f & 43 & 19 & $0 \cdot 127$ \\
& 39 & 21 & $0 \cdot 143$ \\
\hline
\end{tabular}

* Steinbrocker, Traeger, and Battermann (1949). 
TABLE II

SERIAL DIPHENYLAMINE REACTION AND E.S.R. DETERMINATIONS IN 22 PATIENTS WITH RHEUMATOID ARTHRITIS IN STAGES I AND II

\begin{tabular}{|c|c|c|c|c|c|c|c|}
\hline \multirow[b]{2}{*}{ Sex } & \multirow[b]{2}{*}{ Age } & \multicolumn{2}{|c|}{ Before Treatment } & \multicolumn{2}{|c|}{ After 30 days } & \multirow{2}{*}{$\begin{array}{c}\text { Grade } \\
\text { of } \\
\text { Improvement }\end{array}$} & \multirow[b]{2}{*}{ Treatment } \\
\hline & & $\begin{array}{c}\text { Erythrocyte } \\
\text { Sedimentation } \\
\text { Rate }\end{array}$ & $\begin{array}{l}\text { Diphenylamine } \\
\text { Reaction }\end{array}$ & $\begin{array}{c}\text { Erythrocyte } \\
\text { Sedimentation } \\
\text { Rate }\end{array}$ & $\begin{array}{l}\text { Diphenylamine } \\
\text { Reaction }\end{array}$ & & \\
\hline $\begin{array}{l}\mathbf{m} \\
\mathbf{f} \\
\mathbf{m} \\
\mathbf{m} \\
\mathbf{f} \\
\mathbf{f} \\
\mathbf{m} \\
\mathbf{m} \\
\mathbf{f} \\
\mathbf{m} \\
\mathbf{m} \\
\mathbf{m} \\
\mathbf{f} \\
\mathbf{m} \\
\mathbf{m} \\
\mathbf{f} \\
\mathbf{m}\end{array}$ & \begin{tabular}{|l|}
25 \\
38 \\
40 \\
41 \\
26 \\
29 \\
45 \\
30 \\
28 \\
40 \\
34 \\
26 \\
$-1---$ \\
29 \\
27 \\
45 \\
32 \\
41 \\
34 \\
\end{tabular} & $\begin{array}{r}36 \\
26 \\
48 \\
31 \\
36 \\
45 \\
40 \\
31 \\
37 \\
31 \\
48 \\
32 \\
------ \\
30 \\
33 \\
85 \\
101 \\
52 \\
72 \\
\end{array}$ & $\begin{array}{l}0 \cdot 183 \\
0 \cdot 189 \\
0 \cdot 155 \\
0 \cdot 245 \\
0 \cdot 175 \\
0 \cdot 200 \\
0 \cdot 185 \\
0 \cdot 190 \\
0 \cdot 198 \\
0 \cdot 170 \\
0 \cdot 158 \\
0 \cdot 191 \\
-0 .-17--- \\
0 \cdot 178 \\
0 \cdot 240 \\
0 \cdot 201 \\
0 \cdot 168 \\
0 \cdot 173 \\
0 \cdot 220\end{array}$ & $\begin{array}{r}14 \\
6 \\
9 \\
10 \\
5 \\
6 \\
13 \\
14 \\
10 \\
9 \\
12 \\
14 \\
-\frac{-}{21}-- \\
42 \\
27 \\
44 \\
40 \\
45\end{array}$ & $\begin{array}{l}0 \cdot 132 \\
0 \cdot 125 \\
0 \cdot 140 \\
0 \cdot 137 \\
0 \cdot 133 \\
0 \cdot 140 \\
0 \cdot 132 \\
0 \cdot 140 \\
0 \cdot 119 \\
0 \cdot 121 \\
0 \cdot 131 \\
0 \cdot 131 \\
---1-- \\
0 \cdot 140 \\
0 \cdot 131 \\
0 \cdot 130 \\
0 \cdot 128 \\
0 \cdot 138 \\
0 \cdot 142 \\
\end{array}$ & $\begin{aligned} \text { II } \\
\text { II } \\
\text { II } \\
\text { II } \\
\text { I } \\
\text { I } \\
\text { II } \\
\text { II } \\
\text { II } \\
\text { I } \\
\text { II } \\
\text { II } \\
-1 \text { II }-- \\
\text { II } \\
\text { I } \\
\text { II } \\
\text { II } \\
\text { II }\end{aligned}$ & 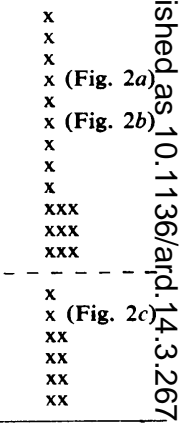 \\
\hline $\begin{array}{l}\mathrm{m} \\
\mathrm{f} \\
\mathrm{m}\end{array}$ & $\begin{array}{l}27 \\
32 \\
30 \\
43\end{array}$ & $\begin{array}{l}35 \\
53 \\
62 \\
45\end{array}$ & $\begin{array}{l}0 \cdot 222 \\
0 \cdot 183 \\
0 \cdot 202 \\
0 \cdot 165\end{array}$ & $\begin{array}{l}30 \\
48 \\
30 \\
37\end{array}$ & $\begin{array}{l}0 \cdot 170 \\
0 \cdot 175 \\
0 \cdot 178 \\
0 \cdot 158\end{array}$ & $\begin{array}{l}\text { III } \\
\text { IV } \\
\text { III } \\
\text { III }\end{array}$ & 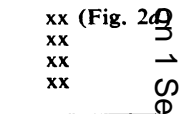 \\
\hline
\end{tabular}

In the second group (fifteen males and seven females between the ages of 25 and 45), the course of the reaction was studied for a period of 30 days, determinations being done every 10 days (Fig. 1).

During this period the patients were under treatment with phenylbutazone by mouth, or hydrocortisone, or a combination of both. The dosage is set out in Table II, which also includes the values obtained at the beginning and end of the investigation.

At the beginning of our observations the colorimetric values of the diphenylamine reaction were consistently high in all patients (maximum $0 \cdot 245$,

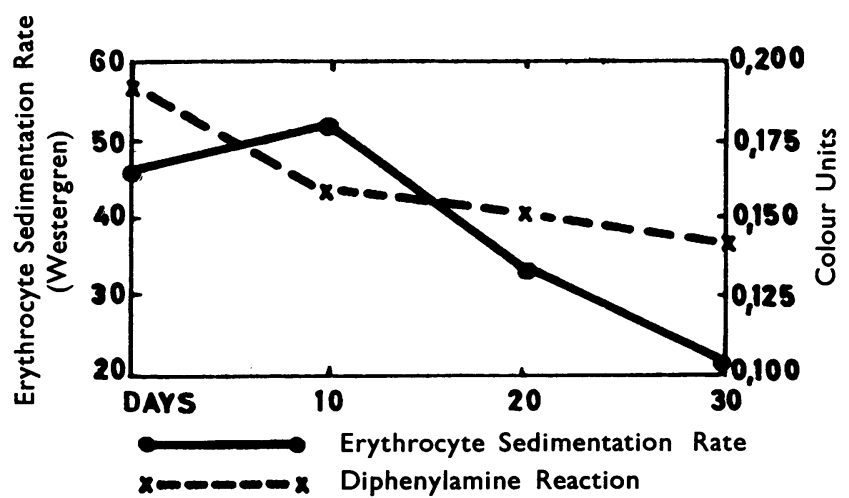

Fig. 1.-Relation of diphenylamine reaction and erythrocyte sedimentation rate in 22 patients with rheumatoid arthritis. minimum $0 \cdot 155$, mean $0 \cdot 190$ ). On the 30 th day dhe. colorimetric values had fallen to normal in eightoet patients (above the continuous line in Table JIF, maximum $0 \cdot 140$, minimum $0 \cdot 119$, mean $0 \cdot 1 \frac{1}{8}$ the values remained above normal in four (below the continuous line in Table II; maximum 0.178 minimum $0 \cdot 158$, mean $0 \cdot 170$ ).

On the 30th day the erythrocyte sedimentatio 8 rate, which was high in all at the beginning of the testing period, had fallen to normal in twelve patients (above the dotted line in Table II, e.g Figs $2 a$ and $b$ ).

The course of the diphenylamine reaction was parallel to that of the clinical condition? that is the eighteen patients in whom the values returned to normal within 30 days. all presented a Grade I or II improvemene while the other four were Grade III and IV.

The erythrocyte sedimentation rat8 remained high in six of the eighteen patients in whom the diphenylamine reaction had. become normal (between the dotted and continuous lines in Table II, e.g. Fig. $2 c$ ).

The diphenylamine reaction returned to normal in all patients treated with hydrow cortisone $(e . g$. Figs $2 a, b, c)$, in all thos treated with hydrocortisone and phenyto butazone, and in four of those treated with phenylbutazone only. The four patients in whom the diphenylamine reaction wa\$ 
(a) Grade II, male aged 41.

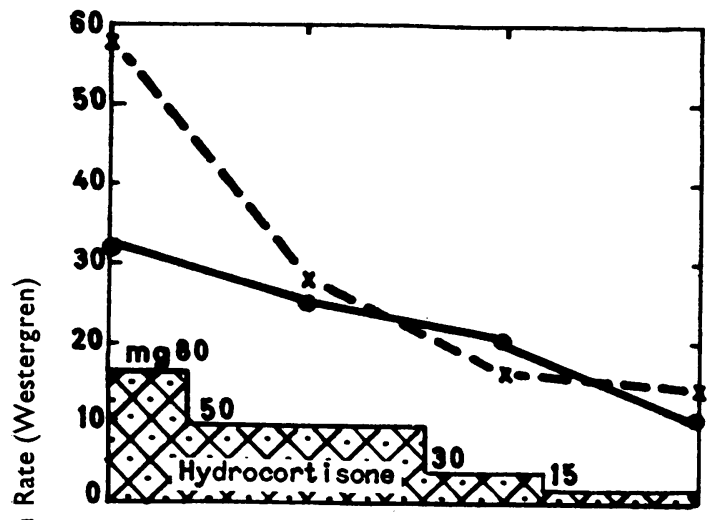

(c) Grade II, female aged 27

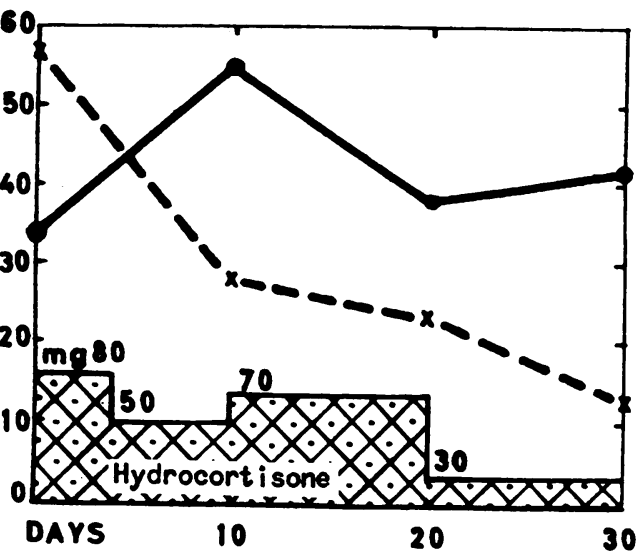

(b) Grade I, female aged 29.

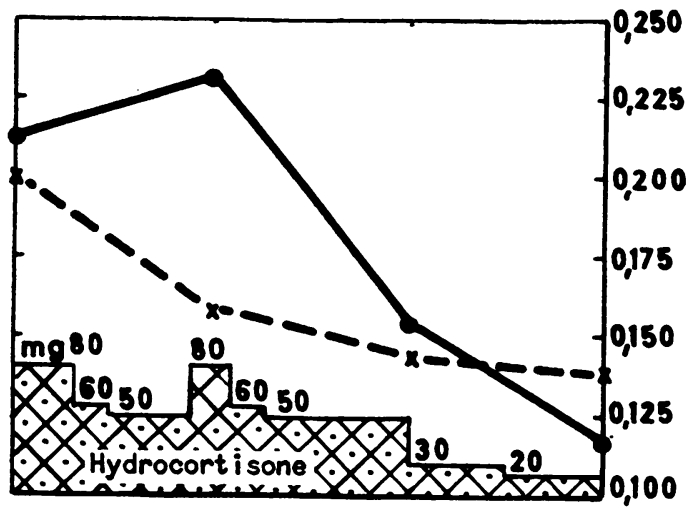

(d) Grade II, male aged 27.

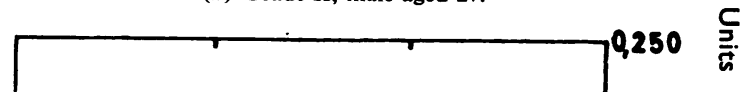

Fig. 2.-Diphenylamine reaction and erythrocyte sedimentation rate in four cases of rheumatoid arthritis (cf. Table II), showing sex, age, dosage, and grade of improvement.

higher than normal at the end of 30 days (below continuous line in Table II) had been treated with phenylbutazone alone (e.g. Fig. 2d).

In seven cases of ankylosing spondylitis (six males and one female, aged from 18 to 55), of whom two -were in the relatively early stages (that is approximately 1 year from the onset of sacro-iliac and vertebral symptoms), moderately raised colorimetric values were found only in the two early cases. The values of 0.174 and 0.169 in these two patients (above the line in Table III) corresponded to a moderate rise in the sedimentation rate.

In one 18-year-old female patient with acute lupus erythematosus, continuous and very high levels were found (from 0.278 to 0.295 ) at monthly intervals; they did not correspond to the clinical picture, and were unaffected by the administration of therapeutic agents.

TABLE III

SERIAL DIPHENYLAMINE REACTION AND E.S.R. DETERMINATIONS IN SEVEN PATIENTS WITH ANKYLOSING SPONDYLITIS

\begin{tabular}{|c|c|c|c|c|c|}
\hline \multirow[b]{2}{*}{ Sex } & \multirow[b]{2}{*}{ Age } & \multicolumn{2}{|c|}{ Before Treatment } & \multicolumn{2}{|c|}{ After 30 days } \\
\hline & & $\begin{array}{c}\text { Erythrocyte } \\
\text { Sedimenta- } \\
\text { tion Rate }\end{array}$ & $\begin{array}{l}\text { Diphenyl- } \\
\text { amine } \\
\text { Reaction }\end{array}$ & $\begin{array}{c}\text { Erythrocyte } \\
\text { Sedimenta- } \\
\text { tion Rate }\end{array}$ & $\begin{array}{l}\text { Diphenyl- } \\
\text { amine } \\
\text { Reaction }\end{array}$ \\
\hline $\mathbf{m}$ & $\begin{array}{l}18 \\
22\end{array}$ & $\begin{array}{l}29 \\
19\end{array}$ & $\begin{array}{l}0 \cdot 174 \\
0 \cdot 169\end{array}$ & $\begin{array}{l}38 \\
32\end{array}$ & $\begin{array}{l}0 \cdot 140 \\
0 \cdot 135\end{array}$ \\
\hline$\underset{\mathrm{f}}{\mathrm{m}}$ & $\begin{array}{l}45 \\
38 \\
27 \\
23 \\
53\end{array}$ & $\begin{array}{r}8 \\
12 \\
18 \\
7 \\
16\end{array}$ & $\begin{array}{l}0 \cdot 128 \\
0 \cdot 132 \\
0 \cdot 125 \\
0 \cdot 140 \\
0 \cdot 138\end{array}$ & $\begin{array}{r}8 \\
10 \\
11 \\
22 \\
15\end{array}$ & $\begin{array}{l}0 \cdot 130 \\
0 \cdot 135 \\
0 \cdot 122 \\
0 \cdot 139 \\
0 \cdot 130\end{array}$ \\
\hline
\end{tabular}




\section{Comment}

This subject, which is still in its infancy but is full of scientific and practical interest in face of the specific immunological reactions caused by bacterial and virus infections, concerns the non-specific reactions not bound to anti-body production, which appear in the blood stream during the acute phase of infections. Reactions similar to the raising of the erythrocyte sedimentation rate occur even during non-infectious diseases and tend to persist in the blood as long as the disease remains active. They probably result from enzymatic adjustments which produce symptoms, anatomical changes, and finally recovery from the disease.

Among these acute-phase reactions, a particular significance seems to belong to the concentration in the blood of a diphenylamine-reactant substance; its exact chemical composition is not yet known, but it is probably a serum muco-protein. Recent studies of rheumatic fever have shown that the diphenylamine reaction is a valuable aid in determining the degree of activity of the disease and the efficacy of the drugs used in treating it.

Our research has shown that this reaction may also be used to test the course of rheumatoid arthritis; the diphenylamine reaction is constantly increased during the active phases of the disease and follows the clinical variations more faithfully and promptly than the erythrocyte sedimentation rate. Even though the absolute colorimetric value is not proportional to the gravity of the disease, it does show very clearly the degree of rheumatoid activity. It is less useful in diagnosis because it is also raised in other conditions, including rheumatic fever and disseminated lupus erythematosus, and is not sufficiently indicative in ankylosing spondylitis.

A most interesting feature was the rapidity with which the serum concentration of the diphenylaminereactant substance fell with the use of hydrocortisone. This change was less marked with phenylbutazone.

\section{Summary}

The behaviour of the diphenylamine reaction is compared with that of the erythrocyte sedimentation rate in thirty cases of rheumatoid arthritis and seven of ankylosing spondylitis in various stages. The values found in the normal individual average 0.134 units with a maximum of 0.140 and a minimum of $0 \cdot 120$ (Unicam spectrophotometer, SP 350).

In active cases of rheumatoid arthritis (Stages I and II) these values were found to be constantly increased (mean $0 \cdot 190$ ), and tended to return to normal with improvement in the clinical picture; the reaction also seemed to be influenced by therapy, especially by hydrocortisone. As a measure of disease activity and of the efficacy of the therapy adopted, the reaction appears to be in general more sensitive than the erythrocyte sedimentation rate.

No significant alteration from normal was e $\overrightarrow{\text {; }}$ countered in cases of rheumatoid arthritis in Stagęs III and IV or in ankylosing spondylitis.

The authors are greatly indebted to Dr. A. Maria $\frac{\overline{\frac{\rho}{m}}}{\mathrm{~m}}$ of the Superior Institute of Health in Rome for his a with the biochemical section of this work.

\section{REFERENCES}

Ayala, W., Moore, L. V., and Hess, E. L. (1951). J. clin. Invest: 30, 781.

Coburn, A. F., and Haninger, J. (1954). J. exp. Med., 99, 1.

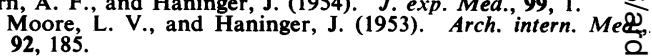

Niazi, S., and State, D. (1948). Cancer Res., 8, 653.

Steinbrocker, O., Traeger, C. H., and Batterman, R. C. (1949) J. Amer. med. Ass., 140, 659.

\section{La réaction sérique de diphénylamine dans l'arthrite rhumatismale}

RÉSUMÉ

On compare le comportement de la réaction dO diphénylamine à celle de la sédimentation globulaire da巴s trente cas d'arthrite rhumatismale et sept cas de spondy arthrite ankylosante aux diverses états de la maladie Chez des sujets normaux o trouva le chiffre moyen of 0,134 unités, avec un maximum de 0,140 et un minimum de 0,120 (spectrophotomètre Unicam, Model SP 3508. $\overrightarrow{0}$

Dans les cas d'arthrite rhumatismale active (états II), ces chiffres augmentaient constamment (moyenne.de 0,190 ) et tendaient à revenir à la normale avec l'améliĝ̣r tion du tableau clinique; cette réaction semblait égạle ment subir l'influence du traitment, surtout par l'hydro cortisone. En tant que mesure de l'activité morbide de l'efficacité du traitement adopté, cette réaction parañ être, en général, plus sensible que la sédimentatiog globulaire.

On n'a pas trouvé de déviations significatives dans de cas d'arthrite rhumatismale aux états III et IV ou des cas de spondylarthrite ankylosante.

\section{La reacción sérica de difenilamina en la artritis reumatoide}

\section{Sumario}

Se compara el comportamiento de la reacción ç difenilamina con la de la sedimentación eritrocitaria ent treinta casos de artritis reumatoide y siete casos \&e espondilartritis anquilosante en varios períodos de enfermedad. En sujetos normales se encontraron valores medios de 0,134 unidades, con un máximo de 0,140 y um mínímo de 0,120 (espectrofotometro Unicam, Mod SP 350).

En los casos de artritis reumatoide activa (periogo: I y II) estos valores aumentaban constantemente (d promedio 0,190 ) y tendían a normalizarse con la mejorja del cuadro clínico; esta reacción parecía también estä bajo la influencia del tratamiento, particularmente de hidrocortisona. Como medida de la actividad mórbida y de la eficacia del tratamiento elegido, esta reacción parece, en general, más sensible que la sedimentaciog globular.

No se encontraron desviaciones significativas en $1 \notin$ casos de artritis reumatoide en períodos III y IV ni ę los de espondilartritis anquilosante. 